\title{
Respon Jamur Merang (volvariella volvacea) terhadap Ketebalan Media Tanam dan Konsentrasi Molase Tetes Tebu
}

\section{Response of Merang Mushroom (volvariella volvacea) to the thickness of the Planting Media and Sugar Drops Molasses Concentration}

\author{
Rama Adi Pratama ${ }^{1}$ \\ ${ }^{1}$ Program Studi Agroteknologi Fakultas Pertanian Universitas Garut \\ Jalan Raya Samarang No. 52 A Tarogong Kidul Kabupaten Garut 44151 \\ e-mail :ramatarigan@uniga.ac.id
}

\begin{abstract}
ABSTRAK
Tingginya permintaan konsumen di Indonesia terhadap komoditas jamur merang belum dapat diimbangi oleh tingkat produksinya. Penelitian dilaksanakan untuk mengetahui pengaruh ketebalan media tanam dan konsentrasi molase tetes tebu terhadap pertumbuhan dan hasil jamur merang (Volvariella volvacea). Percobaan dilaksanakan di Kampung Babakan jambe Desa Pasawahan, Kecamatan Tarogong Kaler, Kabupaten Garut dari bulan Februari sampai Maret 2019. Rancangan yang digunakan dalam penelitian ini adalah metode eksperimental dengan menggunakan Rancangan Acak Kelompok (RAK) pola faktorial $4 \times 4$, faktor pertama adalah ketebalan media tanam $(\mathrm{M})$ yaitu: $\mathrm{m}_{0}=$ ketebalan $5 \mathrm{~cm}, \mathrm{~m}_{1}=$ ketebalan $15 \mathrm{~cm} \mathrm{~m}_{2}=$ ketebalan $25 \mathrm{~cm}, \mathrm{~m}_{3}=$ ketebalan 35 $\mathrm{cm}$. Faktor kedua adalah Konsentrasi Molase (K) yaitu: $\mathrm{k}_{0}=0 \mathrm{ml} / \mathrm{l}$ air, $\mathrm{k}_{1}=5 \mathrm{ml} / \mathrm{l}$ air, $\mathrm{k}_{2}=15 \mathrm{ml} / \mathrm{l}$ air, $\mathrm{k}_{3}=25 \mathrm{ml} / \mathrm{l}$ air. Hasil Penelitian menunjukkan terjadi interaksi antara ketebalan media tanam dan konsentrasi molase tetes tebu terhadap waktu keluar pinhead. Nilai interaksi tertinggi terdapat pada kombinasi perlakuan ketebalan media tanam15 $\mathrm{cm}\left(\mathrm{m}_{1}\right)$ dan konsentrasi molase tetes tebu $5 \mathrm{ml} / \mathrm{l}$ $\left(\mathrm{k}_{1}\right)$.Secara mandiri ketebalan media tanam dan konsentrasi ketebalan molase tetes tebu ketebalan media tanam $25 \mathrm{~cm}\left(\mathrm{~m}_{2}\right)$ menuunjukan pengaruh nyata terhadap karakter jumlah tubuh buah periode 1, grade 1, II, III dan bobot panen periode 1 . Kombinasi terbaik selanjutnya pada konsentrasi molase $5 \mathrm{ml} / \mathrm{l}\left(\mathrm{k}_{1}\right)$ ditunjukan dengan hasil tertinggi pada seluruh karakter pengamatan.
\end{abstract}

Kata kunci : ketebalan media tanam, konsentrasi molase tetes tebu, jamur merang (Volvariella volvacea).

\begin{abstract}
The high consumer demand in Indonesia for the community of mushroom cannot be balanced by the level of the product. The research was conducted to determine the effect of the thickness of the planting medium and the concentration of Molasses in the growth and yield of the mushroom (Vorvariella volvacea). The experiment was conducted in Babakab jambe, Pasawahan Village, Tarogong Kaler District, Garut Regency from February to March 2019. The design used in this study was an experimental method using factorial Randomized Block Design
\end{abstract}


(RBD) of $4 \times 4$, the first factor was the Thickness of the Planting Medium (M) namely : $m_{0}=5 \mathrm{~cm}$ Thickness, $m_{1}=15 \mathrm{~cm}$ Thickness, $m_{2}=25 \mathrm{~cm}$ Thickness, $m_{3}$ $=35 \mathrm{~cm}$ Thickness. The second factor is the concentration of Molasses (K), namely: $k_{0}=0 \mathrm{ml} / \mathrm{l}$ water, $k_{1}=5 \mathrm{ml} / l$ water, $k_{2}=15 \mathrm{ml} / l$ water, $k_{3}=25 \mathrm{ml} / l$ water. The results showed that there was an interaction between the thickness of the planting medium and the concentration of Molasses on Pinhead Discharge time. The highest interaction value is found in the combination treatment of thickness of the planting medium $15 \mathrm{~cm}$ Trickness $\left(m_{1}\right)$ and concentration of Molasses $5 \mathrm{ml} / \mathrm{l}$ water $\left(k_{1}\right)$. Independently the of the planting medium $25 \mathrm{~cm}$ Thickness $\left(m_{2}\right)$ of shows the significant effect on Many fruit body period 1, grade I, II III, and period I harvest weigh. The next best highest in the treatmen of 15 $\mathrm{ml} / \mathrm{l}$ water $\left(k_{2}\right)$ is show with the heighest results in all observational Character.

Keywords: Thickness of the Planting Medium, Concentration of Molasses, Mushroom, Volvariella volvacea.

\section{PENDAHULUAN}

Jamur merang merupakan suatu komoditas bidang pertanian yang cukup digemari oleh konsumen karena rasanya yang lezat serta cukup mudah untuk diolah. Jamur merang juga sering digunakan pada aspek medis, karena itu jamur sangat baik bagi kesehatan. Jamur merang mengandung protein sebesar 5.94\%, karbohidrat 0,59\%, lemak 0,17\%, abu 1,14\%, serat 1,56\%, besi 1,9 mg, fosfor 17 $\mathrm{mg}$, vitamin B-1 0,15 mg, vitamin B-2 0,75 mg, dan vitamin C 12,40 mg (Wijaya, 2014).

Tingginya permintaan konsumen terhadap komoditas jamur belum dapat diimbangi dengan tingkat produksinya. Produksi jamur di Indonesia pada tahun 2011 sampai 2014 cenderung fluktuatif, pada tahun 2011 produksi jamur di Indonesia sebanyak 45.854 ton, tahun 2012 menurun menjadi 40.886 ton, tahun 2013 meningkat kembali menjadi 44.565 ton dan pada tahun 2014 menurun menjadi 37.410 ton (Kementan, 2015). Peningkatan konsumsi masyarakat tidak sebanding dengan produksi yang fluktuatif, sehingga diperlukan adanya peningkatan produksi jamur.

Upaya yang dilakukan untuk meningkatkan produksi jamur, khususnya jamur merang, diperlukan beberapa tahapan yang harus dilakukan dalam sistem budidayanya. Tahapan itu diantaranya pembuatan kumbung, fermentasi untuk media tumbuh, pembuatan media, penyiraman, proses pemeliharaan, pengendalian hama dan penyakit, panen dan pasca panen. Cara budidaya jamur 
merang harus dilakukan dengan baik guna menghasilkan jamur yang berkualitas. Pemilihan media tanam sangat berpengaruh terhadap pertumbuhan jamur (Zuyasna dkk, 2011).

Inovasi teknologi yang sering dilakukan petani jamur adalah pengaturan media tanam. Ketepatan pengaturan jenis dan ketebalan media tanam akan berpengaruh pada tingkat hasil. Semakin baik media yang digunakan maka diasumsikan semakin baik pula pertumbuhan jamur yang dihasilkan karena media yang baik akan memiliki kandungan nutrisi yang dibutuhkan jamur pada proses budidaya (Zuyasna dkk, 2011).

Jamur merang umumnya tumbuh pada media yang merupakan sumber selulosa, seperti limbah pertanian dan limbah industri. Limbah pertanian berupa bekas serpihan daun sayuran, serbuk gergaji dan lain-lain. Limbah industri berupa kardus menjadi pilihan karena mudah diperoleh serta berpengaruh baik pada kualitas jamur. Ketepatan pengaturan jenis dan ketebalan media tanam, kelembapan dan nutrisi juga menjadi salah satu faktor yang memengaruhi pertumbuhan jamur merang (Sinaga, 2011).

Nutrisi yang digunakan yaitu molase dari hasil produksi pabrik gula tebu yang tidak dapat dikristalkan lagi dan berbentuk cairan hitam yang kental. Kandungan gula yang rendah dan merupakan salah satu bahan alternatif yang dapat digunakan sebagai nutrisi tambahan pada media tumbuh jamur, molase mengandung glukosa, fruktosa, nitrogen, kalsium, magnesium, potasium dan besi yang dapat digunakan untuk memenuhi kebutuhan nutrisi pada jamur sebagai sumber energi untuk metabolisme sel jamur yang akan merangsang pertumbuhan miselium. Molase juga memiliki kandungan unsur nitrogen berkisar antara $2 \%$ sampai 6\% yang berfungsi untuk membangun miselium (Puspaningrum, 2013).

Molase pekat berasal dari cairan gula yang diuapkan sehingga mengandung 70 sampai 80\% gula yang terdiri dari 70\% gula invert (Purwani dkk, 2007). Tingginya kandungan gula pada molase membuat molase sering dijadikan sebagai tambahan sumber karbohidrat pada medium pertumbuhan mikroorganisme (Sebayang, 2006). Pengaplikasian molase ini banyak dilakukan terhadap komoditas jamur tiram namun belum banyak dilakukan pada komoditas 
jamur merang. Maka dari itu, penulis memilih untuk mengaplikasikannya pada jamur merang.

Penelitian ini bertujuan untuk mengetahui efek interaksi antara berbagai ketebalan media tanam dan konsentrasi molase tetes tebu terhadap pertumbuhan dan hasil jamur merang dan mengetahui pengaruh mandiri antara berbagai ketebalan media tanam dan konsentrasi molase tetes tebu terhadap pertumbuhan dan hasil jamur merang.

\section{METODOLOGI PENELITIAN}

Percobaan dilaksanakan di Kampung Babakan Jambe Desa Pasawahan, Kecamatan Tarogong Kaler, Kabupaten Garut pada bulan Februari sampai dengan bulan Maret 2019 dengan ketinggian tempat $738 \mathrm{~m}$ di atas permukaan laut.

Bahan yang digunakan dalam percobaan adalah bibit jamur merang, limbah kardus, limbah sayuran, dedak, arang sekam, bonggol pisang, pupuk NPK, bokasi kotoran hewan, molase tetes tebu dan kapur pertanian $\left(\mathrm{CaCO}_{3}\right)$.Alat-alat yang digunakan dalam percobaan ini adalah plastik, alat tulis, mistar, ember, timbangan, thermometer, hygrometer, $\mathrm{pH}$ meter, timbangan digital, pisau, gunting, baki panen, sarung tangan, dan kamera digital.

Metode penelitian yang digunakan adalah metode eksperimental, dengan Rancangan Acak Kelompok (RAK) berpola faktorial 4 x 4 dengan dua kali ulangan. Faktor pertama adalah media tanam (M) dengan empat taraf dan faktor kedua yaitu kosentrasi pemberian molase (K) dengan empat taraf. Faktor pertama adalah media tanam $(\mathrm{M})$ yang terdiri atas empat taraf, yaitu: $\mathrm{m}_{0}:$ ketebalan $5 \mathrm{~cm}$, $\mathrm{m}_{1}$ : ketebalan $15 \mathrm{~cm}, \mathrm{~m}_{2}$ : ketebalan $25 \mathrm{~cm}$ dan $\mathrm{m}_{3}$ : ketebalan $35 \mathrm{~cm}$. Faktor kedua adalah kosentrasi molase $(\mathrm{K})$ yang terdiri atas empat taraf, yaitu : $\mathrm{k}_{0}: 0 \mathrm{ml} / \mathrm{L}$ air, $\mathrm{k}_{1}: 5 \mathrm{ml} / \mathrm{L}$ air, $\mathrm{k}_{2}: 15 \mathrm{ml} / \mathrm{L}$ air dan $\mathrm{k}_{3}: 25 \mathrm{ml} / \mathrm{L}$ air.

\section{HASIL DAN PEMBAHASAN}

\section{Waktu Keluar Pinhead (HST)}

Hasil analisis statistik menunjukkan terjadi interaksi antara ketebalan media tanam dan pemberian konsentrasi molase terhadap waktu keluar pinhead dapat 
dilihat pada Tabel 3. Secara terpisah masing-masing perlakuan berpengaruh terhadap waktu keluarnya pinhead. .6.

Tabel 3. Rata-rata Waktu Keluar Pinhead (HST)

\begin{tabular}{ccccc}
\hline \multirow{2}{*}{ Perlakuan } & \multicolumn{4}{c}{ Rata-rata Waktu keluar pinhead (HST) } \\
\cline { 2 - 5 } Konsentrasi & $\mathrm{m}_{0}=5 \mathrm{~cm}$ & $\mathrm{~m}_{1}=15 \mathrm{~cm}$ & $\mathrm{~m}_{2}=25 \mathrm{~cm}$ & $\mathrm{~m}_{3}=35 \mathrm{~cm}$ \\
Molase & $0,00 \mathrm{a}$ & $23,00 \mathrm{a}$ & $18,00 \mathrm{a}$ & $17,00 \mathrm{a}$ \\
& $\mathrm{A}$ & $\mathrm{B}$ & $\mathrm{B}$ & $\mathrm{B}$ \\
$\mathrm{k}_{0}=0 \mathrm{ml} / 1$ & $22,00 \mathrm{~b}$ & $19,50 \mathrm{a}$ & $20,50 \mathrm{a}$ & $21,50 \mathrm{a}$ \\
& $\mathrm{A}$ & $\mathrm{A}$ & $\mathrm{A}$ & $\mathrm{A}$ \\
$\mathrm{k}_{1}=5 \mathrm{ml} / 1$ & $21,50 \mathrm{~b}$ & $20,50 \mathrm{a}$ & $18,00 \mathrm{a}$ & $18,00 \mathrm{a}$ \\
& $\mathrm{A}$ & $\mathrm{A}$ & $\mathrm{A}$ & $\mathrm{A}$ \\
$\mathrm{k}_{2}=15 \mathrm{ml} / 1$ & $20,50 \mathrm{~b}$ & $24,00 \mathrm{a}$ & $16,00 \mathrm{a}$ & $18,50 \mathrm{a}$ \\
& $\mathrm{AB}$ & $\mathrm{B}$ & $\mathrm{A}$ & $\mathrm{AB}$ \\
$\mathrm{k}_{3}=25 \mathrm{ml} / 1$ & $\mathrm{y}$ &
\end{tabular}

Keterangan: Angka rata-rata pada kolom yang diikuti huruf yang sama tidak berbeda nyata menurut Uji Jarak Berganda Duncan pada taraf 5\%.

Berdasarkan Tabel 3 menunjukkan interaksi antara ketebalan media tanam dan pemberian konsentrasi molase terhadap waktu keluar pinhead. Pada arah horizontal faktor perlakuan ketebalan media tanam pada taraf faktor $\mathrm{m}_{0}$ menunjukkan taraf faktor $\mathrm{k}_{1}$ tidak berbeda nyata dengan $\mathrm{k}_{2}$ dan $\mathrm{k}_{3}$, namun berbeda nyata dengan $\mathrm{k}_{0}$.

Arah vertikal menunjukkan faktor perlakuan frekuensi aplikasi berpengaruh nyata terhadap konsentrasi molase. Faktor perlakuan frekuensi aplikasi pada taraf faktor $\mathrm{k}_{0}$ menunjukkan taraf faktor $\mathrm{m}_{0}$ berbeda nyata dengan semua taraf faktor $m_{1} m_{2}$, dan $m_{3}$, taraf faktor $m_{1}$ tidakberbeda nyata dengan $m_{2}$ dan $m_{3}$. Taraf faktor $\mathrm{m}_{2}$ berbeda nyata dengan taraf faktor $\mathrm{m}_{0}$. Taraf faktor $\mathrm{m}_{3}$ tidak berbeda nyata dengan taraf faktor $\mathrm{m}_{2}$ dan $\mathrm{m}_{3}$. Namun tidak berbeda nyata dengan $\mathrm{m}_{0}$.

Faktor perlakuan frekuensi aplikasi pada taraf faktor $\mathrm{k}_{1}$ dan $\mathrm{k}_{2}$ menunjukkan semua taraf faktor baik itu $\mathrm{m}_{0}, \mathrm{~m}_{1}, \mathrm{~m}_{2}$, maupun $\mathrm{m}_{3}$ tidak berbeda nyata. Faktor perlakuan frekuensi aplikasi pada taraf faktor $\mathrm{k}_{3}$ menunjukkan taraf faktor $\mathrm{m}_{0}$ berbeda nyata dengan taraf faktor $\mathrm{m}_{1}$ dan $\mathrm{m}_{2}$, namun tidak berbeda nyata dengan taraf faktor $m_{3}$. Taraf faktor $m_{1}$ berbeda nyata dengan taraf faktor $m_{2}$, namun tidak berbeda nyata dengan taraf faktor $m_{0}$ dan $m_{3}$, taraf faktor $m_{3}$ berbeda nyata dengan taraf faktor $m_{1}$ dan $m_{2}$, namun tidak berbeda nyata dengan taraf faktor $m_{0}$, taraf 
faktor $m_{2}$ berbeda nyata dengan taraf faktor $m_{1}$, namun tidak berbeda nyata dengan taraf faktor $m_{0}$ dan $m_{3}$.

Hal ini terjadi salah satunya karena kandungan nutrisi pada media tanam yang seimbang dan tercukupi pada masa awal pertumbuhan jamur merang hal ini terjadi karena molase memiliki kandungan kalori dan sukrosa yang cukup tinggi. Disampaikan oleh Hambali dkk (2007), bahwa molase juga mengandung karbohidrat berkisar $60 \%$ yang sangat diperlukan pada masa awal pertumbuhan. Molase yang sudah di aplikasikan akan diserap dengan bantuan enzim yang di produksi oleh hifa atau bagian jamur yang bentuknya sepeti benang halus, panjang dan kadang bercabang. Hifa menguraikan nutrisi menjadi senyawa yang dapat diserap untuk pertumbuhan jamur (Parjimo dkk, 2007).

\section{Jumlah Jamur}

Hasil analisis ragam terhadap jumlah jamur periode I dan II dapat dilihat pada Tabel 4. Jumlah waktu panen dikelompokkan menjadi dua periode dengan masing-masing periode enam kali pemanenan. Hasil analisis ragam menunjukkan tidak terjadi interaksi antara perlakuan ketebalan media tanam dan pemberian konsentrasi molase terhadap jumlah jamur periode I dan II, tetapi secara tepisah hanya perlakuan ketebalan media tanam yang menunjukkan pengaruh berbeda nyata hanya pada periode I saja. Rata-rata jumlah jamur periode I nilai tertinggi perlakuan ketebalan media tanam yaitu ketebalan $25 \mathrm{~cm}$, sedangkan nilai tertinggi pada perlakuan konsentrasi molase yaitu konsentrasi $15 \mathrm{ml} / \mathrm{l}$. Periode II nilai tertinggi yaitu taraf faktor $\mathrm{m}_{3}$ yaitu ketebalan $35 \mathrm{~cm}$. Pada faktor perlakuan konsentrasi molase nilai tertinggi yaitu pada konsentrasi $15 \mathrm{ml} / \mathrm{l}$.

Berdasarkan Tabel 4 periode I faktor perlakuan ketebalan media tanam menunjukkan taraf faktor $m_{0}$ tidak berbeda nyata dengan taraf faktor $m_{1}$ dan $m_{3}$ namun berbeda nyata dengan taraf faktor $\mathrm{m}_{2}$. Taraf faktor $\mathrm{m}_{2}$ berbeda nyata dengan taraf faktor $m_{0}$ dan $m_{1}$ namun tidak berbedanyata dengan taraf faktor $m_{3}$. Faktor perlakuan konsentrasi molase pada taraf $\mathrm{k}_{0} \mathrm{k}_{1} \mathrm{k}_{2}$ dan $\mathrm{k}_{3}$ tidak berbeda nyata satu dengan yang lainnya. Periode II faktor perlakuan ketebalan media tanam menunjukkan semua taraf faktor $\mathrm{m}_{0}, \mathrm{~m}_{1}, \mathrm{~m}_{2}$ dan $\mathrm{m}_{3}$ tidak berbeda nyata antara satu dengan yang lainnya. Faktor perlakuan konsentrasi molase menunjukkan 
semua taraf faktor $\mathrm{k}_{0}, \mathrm{k}_{1}, \mathrm{k}_{2}$ dan $\mathrm{k}_{3}$ tidak terjadi interaksi antara satu dengan yang lainnya.

Tabel 4. Rata-rata Jumlah Tubuh Buah

\begin{tabular}{|c|c|c|}
\hline \multirow[t]{2}{*}{ Perlakuan } & \multicolumn{2}{|c|}{ Rata-Rata Jumlah Tubuh Buah } \\
\hline & Periode I & Periode II \\
\hline \multicolumn{3}{|l|}{ Ketebalan Media (M) } \\
\hline $\mathrm{m}_{0}:$ ketebalan $5 \mathrm{~cm}$ & $2,13 \mathrm{a}$ & $2,25 \mathrm{a}$ \\
\hline $\mathrm{m}_{1}$ : ketebalan $15 \mathrm{~cm}$ & $1,50 \mathrm{a}$ & $3,25 \mathrm{a}$ \\
\hline $\mathrm{m}_{2}$ : ketebalan $25 \mathrm{~cm}$ & $15,63 \mathrm{~b}$ & $4,63 \mathrm{a}$ \\
\hline $\mathrm{m}_{3}:$ ketebalan $35 \mathrm{~cm}$ & $10,50 \mathrm{ab}$ & $5,75 \mathrm{a}$ \\
\hline \multicolumn{3}{|l|}{ Konsentrasi Molase (K) } \\
\hline $\mathrm{k}_{0}:$ tanpa molase & $5,38 \mathrm{a}$ & $2,88 \mathrm{a}$ \\
\hline $\mathrm{k}_{1}:$ molase $5 \mathrm{ml} / \mathrm{l}$ & $7,13 \mathrm{a}$ & $4,50 \mathrm{a}$ \\
\hline $\mathrm{k}_{2}:$ molase $15 \mathrm{ml} / \mathrm{l}$ & $9,50 \mathrm{a}$ & $6,00 \mathrm{a}$ \\
\hline $\mathrm{k}_{3}:$ molase $25 \mathrm{ml} / 1$ & $7,75 \mathrm{a}$ & $2,50 \mathrm{a}$ \\
\hline
\end{tabular}

Keterangan : Angka rata-rata pada kolom yang diikuti huruf yang sama tidak berbeda nyata menurut Uji Jarak Berganda Duncan pada taraf 5\%.

Pertumbuhan umlah jamur yang dihasilkan pada tiap plot dapat dipengaruhi oleh kelembapan, suhu dan juga dipengaruhi oleh nutrisi pada media tumbuh yang bisa memengaruhi pertumbuhan jamur sehingga akan memengaruhi jumlah spora yang berkecambah, ketebalan media tanam akan memengaruhi jumlah kandungan nutrisi pada media tanam. Ketebalan media yang berlebihan akan menyebabkan banyak organisme lain tumbuh pada media sehingga pembentukan tubuh buah terhambat dan produktifitasnya menurun (Sinaga, 2012). Menurut Riduan dkk, (2013) bahwa ketebalan media $30 \mathrm{~cm}$ berpengaruh terhadap jumlah badan buah.

Perlakuan pemberian molase tidak menunjukkan berbeda nyata tetapi hasil terbaik didapat pada periode I yaitu pada perlakuan molase $15 \mathrm{ml} / \mathrm{l}\left(\mathrm{k}_{2}\right)$. Menurut Puspaningrum dkk, (2013) perlakuan molase $22 \mathrm{ml} / \mathrm{l}$ berpengaruh terhadap jumlah tubuh buah dan berat buah.

\section{Bobot Jamur (gram)}

Hasil analisis ragam terhadap jumlah jamur periode I dan II dapat dilihat pada Tabel 5. Hasil analisis ragam menunjukkan tidak terjadi interaksi antara perlakuan ketebalan media tanam dan pemberian konsentrasi molase terhadap jumlah jamur periode I dan II, tetapi secara tepisah hanya perlakuan ketebalan 
media tanam yang menunjukkan pengaruh yang berbeda nyata hanya pada periode I saja. Rata-rata jumlah jamur periode I dan II yang diberi perlakuan ketebalan media tanam $25 \mathrm{~cm}\left(\mathrm{~m}_{2}\right)$ berbeda nyata dengan perlakuan ketebalan media $5 \mathrm{~cm}$ $\left(\mathrm{m}_{0}\right), 15 \mathrm{~cm}\left(\mathrm{~m}_{1}\right)$ dan $35 \mathrm{~cm}\left(\mathrm{~m}_{3}\right)$.

Rata-rata jumlah jamur periode I dan II nilai tertinggi pada faktor perlakuan ketebalan media tanam yaitu ketebalan $25 \mathrm{~cm}$, nilai tertinggi faktor perlakuan konsentrasi molase yaitu pada konsentrasi $15 \mathrm{ml} / \mathrm{l}$.

Berdasarkan Tabel 5 pada periode I faktor perlakuan ketebalan media tanam menunjukkan taraf faktor $m_{0}$ tidak berbeda nyata dengan taraf faktor $m_{1}$ dan $m_{3}$ namun berbeda nyata dengan taraf faktor $\mathrm{m}_{2}$. Taraf faktor $\mathrm{m}_{2}$ berbeda nyata dengan taraf faktor $\mathrm{m}_{0}$ dan $\mathrm{m}_{1}$ namun tidak berbeda nyata dengan taraf faktor $\mathrm{m}_{3}$. Faktor perlakuan konsentrasi molase pada taraf $\mathrm{k}_{0}, \mathrm{k}_{1}, \mathrm{k}_{2}$ dan $\mathrm{k}_{3}$ tidak berbeda nyata satu dengan yang lainnya.

Periode II faktor perlakuan ketebalan media tanam menunjukkan semua taraf faktor $m_{0}, m_{1}, m_{2}$ dan $m_{3}$ tidak berbeda nyata antara satu dengan yang lainnya. Faktor perlakuan konsentrasi molase menunjukkan semua taraf faktor $\mathrm{k}_{0}$, $\mathrm{k}_{1}, \mathrm{k}_{2}$ dan $\mathrm{k}_{3}$ tidak terjadi interaksi antara satu dengan yang lainnya.

Tabel 5. Rata-rata Bobot Jamur per Plot (gram)

\begin{tabular}{lcc}
\hline \multicolumn{1}{c}{ Perlakuan } & \multicolumn{2}{c}{ Rata-Rata Bobot Jamur } \\
\cline { 2 - 3 } & Periode I & Periode II \\
\hline Ketebalan Media $(\mathrm{M})$ & $41,38 \mathrm{a}$ & $51,88 \mathrm{a}$ \\
$\mathrm{m}_{0}:$ ketebalan $5 \mathrm{~cm}$ & $37,00 \mathrm{a}$ & $83,38 \mathrm{a}$ \\
$\mathrm{m}_{1}:$ ketebalan $15 \mathrm{~cm}$ & $538,70 \mathrm{~b}$ & $122,63 \mathrm{a}$ \\
$\mathrm{m}_{2}:$ ketebalan $25 \mathrm{~cm}$ & $333,38 \mathrm{ab}$ & $118,3 \mathrm{a}$ \\
$\mathrm{m}_{3}:$ ketebalan $35 \mathrm{~cm}$ & & \\
\hline Konsentrasi Molase $(\mathrm{K})$ & $158,08 \mathrm{a}$ & $66,63 \mathrm{a}$ \\
$\mathrm{k}_{0}:$ tanpa molase & $181,50 \mathrm{a}$ & $89,50 \mathrm{a}$ \\
$\mathrm{k}_{1}:$ molase $5 \mathrm{ml} / 1$ & $316,13 \mathrm{a}$ & $150,63 \mathrm{a}$ \\
$\mathrm{k}_{2}:$ molase $15 \mathrm{ml} / 1$ & $294,75 \mathrm{a}$ & $69,25 \mathrm{a}$ \\
$\mathrm{k}_{3}:$ molase $25 \mathrm{ml} / 1$ & &
\end{tabular}

Keterangan : Angka rata-rata pada setiap kolom diikuti huruf yang sama tidak berbeda nyata menurut Uji Jarak Berganda Duncan pada taraf 5\%.

Jamur yang dihasilkan dengan bobot terbaik dihasilkan dari pertumbuhan jamur yang optimal dan hal tersebut tentunya akan dipengaruhi oleh suhu, 
kelembapan dan kandungan nutrisi pada media tanam, karena semakin tebal media diasumsikan ketersediaan nutrisi akan semakin banyak. Ketepatan pengaturan jenis dan ketebalan media tanam, kelembapan dan nutrisi juga menjadi salah satu faktor yang mempengarui pertumbuhan jamur merang (Sinaga, 2012).

Perlakuan pemberian molase tidak berbeda nyata baik pada periode I dan periode II tetapi hasil terbaik didapat pada perlakuan molase $15 \mathrm{ml} / 1\left(\mathrm{k}_{2}\right)$ pada periode I. Menurut Puspaningrum dkk, (2013) menyatakan konsentrasi pemberian molase $22 \mathrm{ml} / \mathrm{l}$ berpengaruh terhadap jumlah dan berat buah.

\section{Tinggi Tubuh Buah (mm)}

Hasil analisis ragam terhadap tinggi tubuh buah jamur periode I dan II dapat dilihat pada Tabel 6. Hasil analisis ragam menunjukkan tidak terjadi interaksi antara perlakuan ketebalan media tanam dan pemberian konsentrasi molase terhadap jumlah jamur periode I dan II, tetapi secara tepisah hanya perlakuan ketebalan media tanam yang menunjukkan pengaruh yang berbeda nyata hanya pada periode I saja. Rata-rata jumlah jamur periode I nilai tertinggi perlakuan ketebalan media tanam yaitu dengan ketebalan $35 \mathrm{~cm}$, sedangkan nilai tertinggi pada perlakuan konsentrasi molase yaitu pada konsentrasi $15 \mathrm{ml} / \mathrm{l}$. Periode II nilai tertinggi diperoleh pada taraf faktor $m_{3}$ yaitu ketebalan $15 \mathrm{~cm}$. Pada faktor perlakuan konsentrasi molase nilai tertinggi yaitu pada konsentrasi $15 \mathrm{ml} / \mathrm{l}$.

Berdasarkan Tabel 6 pada periode I faktor perlakuan ketebalan media tanam menunjukkan taraf faktor $\mathrm{m}_{0}$ tidak berbeda nyata dengan taraf faktor $\mathrm{m}_{1}$, namun berbeda nyata dengan $m_{2}$ dan $m_{3}$. Taraf faktor $m_{2}$ berbeda nyata dengan taraf faktor $\mathrm{m}_{0}$, namun tidak berbedanyata dengan taraf faktor $\mathrm{m}_{1}$ dan $\mathrm{m}_{3}$. Faktor perlakuan konsentrasi molase pada taraf $\mathrm{k}_{0}, \mathrm{k}_{1}, \mathrm{k}_{2}$ dan $\mathrm{k}_{3}$ tidak berbeda nyata satu dengan yang lainnya.

Periode II faktor perlakuan ketebalan media tanam menunjukkan semua taraf faktor $\mathrm{m}_{0}, \mathrm{~m}_{1}, \mathrm{~m}_{2}$ dan $\mathrm{m}_{3}$ tidak berbeda nyata antara satu dengan yang lainnya. Faktor perlakuan konsentrasi molase menunjukkan semua taraf faktor $\mathrm{k}_{0}$, $\mathrm{k}_{1}, \mathrm{k}_{2}$ dan $\mathrm{k}_{3}$ tidak terjadi interaksi antara satu dengan yang lainnya.

Tinggi tubuh buah jamur dipengaruhi oleh kelembapan, suhu dan jumlah nutrisi, karena nutrisi yang terkandung pada media tanam yang cukup akan 
membuat jamur tumbuh dengan optimal karena jika jumlah nutrisi pada media tanam kurang otomatis akan menyebabkan jamur terhabat pertumbuhannya.

Tabel 6. Rata-rata Tinggi Tubuh Buah (mm)

\begin{tabular}{lcc}
\hline \multicolumn{1}{c}{ Perlakuan } & \multicolumn{2}{c}{ Rata-rata Tinggi Tubuh Buah } \\
\cline { 2 - 3 } & Periode I & Periode II \\
\hline Ketebalan Media $(\mathrm{M})$ & $10,06 \mathrm{a}$ & $17,76 \mathrm{a}$ \\
$\mathrm{m}_{0}:$ ketebalan $5 \mathrm{~cm}$ & $14,09 \mathrm{ab}$ & $24,45 \mathrm{a}$ \\
$\mathrm{m}_{1}:$ ketebalan $15 \mathrm{~cm}$ & $28,36 \mathrm{~b}$ & $21,35 \mathrm{a}$ \\
$\mathrm{m}_{2}:$ ketebalan $25 \mathrm{~cm}$ & $29,39 \mathrm{~b}$ & $23,51 \mathrm{a}$ \\
$\mathrm{m}_{3}:$ ketebalan $35 \mathrm{~cm}$ & & \\
\hline Konsentrasi Molase $(\mathrm{K})$ & $16,93 \mathrm{a}$ & $15,38 \mathrm{a}$ \\
$\mathrm{k}_{0}:$ tanpa molase & $21,56 \mathrm{a}$ & $22,06 \mathrm{a}$ \\
$\mathrm{k}_{1}:$ molase $5 \mathrm{ml} / 1$ & $25,48 \mathrm{a}$ & $27,79 \mathrm{a}$ \\
$\mathrm{k}_{2}:$ molase $15 \mathrm{ml} / 1$ & $17,94 \mathrm{a}$ & $21,85 \mathrm{a}$ \\
$\mathrm{k}_{3}:$ molase $25 \mathrm{ml} / 1$ & &
\end{tabular}

Keterangan: Angka rata-rata pada kolom yang diikuti huruf yang sama tidak berbeda nyata menurut Uji Jarak Berganda Duncan pada taraf 5\%.

Menurut Agus dkk, (2002) menyatakan kelembapan udara untuk pertumbuhan jamur adalah 75 sampai 85\%, tingkat kelembapan $75 \%$ berpengaruh terhadap pembentukan miselium, kelembapan 80 sampai $85 \%$ berpengaruh terhadap pembentukan tubuh buah, kemungkinan pembentukan miselium dari spora akan gagal jika kelembapan teralu rendah dan akan rawan busuk jika kelembapan terlalu tinggi. Ketebalan media tanam, kelembapan dan nutrisi menjadi salah satu faktor yang memengaruhi pertumbuhan jamur merang (Sinaga, 2012).

Pemberian konsentrasi molase tidak memberikan pengaruh yang nyata terhadap tinggi tubuh buah pada periode I dan periode II, hasil terbaik didapat pada perlakuan molase $15 \mathrm{ml} / \mathrm{l}\left(\mathrm{k}_{2}\right)$ pada periode I dan periode II, hal tersebut karena dipengaruhi oleh kandungan nutrisi molase pada media tanam. Sedangkan pada faktor ketebalan media hasil terbaik didapat pada ketebalan $35 \mathrm{~cm}\left(\mathrm{~m}_{3}\right)$.

\section{Grade Jamur Per Plot (mm)}

Hasil analisis ragam terhadap grade jamur I, II dan III dapat dilihat pada Tabel 4. Hasil analisis ragam menunjukkan tidak terjadi interaksi antara perlakuan ketebalan media tanam dan pemberian konsentrasi molase terhadap grade jamur I, 
II dan III, tetapi secara tepisah hanya perlakuan ketebalan media tanam yang menunjukkan pengaruh yang berbeda nyata hanya pada grade I saja. Rata-rata grade jamur I, II dan III nilai tertinggi ketebalan media tanam yaitu ketebalan 25 $\mathrm{cm}$ dan nilai tertinggi konsentrasi molase yaitu dengan konsentrasi $15 \mathrm{ml} / \mathrm{l}$.

Berdasarkan Tabel 7 pada grade I faktor perlakuan ketebalan media tanam menunjukkan taraf faktor $m_{0}$ tidak berbedanyata dengan taraf faktor $m_{1}$ namun berbeda nyata dengan taraf faktor $m_{2}$ dan $m_{3}$. Taraf faktor $m_{2}$ berbeda nyata dengan taraf faktor $m_{0}$ dan $m_{1}$ namun tidak berbedanyata dengan taraf faktor $m_{3}$. Faktor perlakuan konsentrasi molase pada taraf $\mathrm{k}_{0}, \mathrm{k}_{1}, \mathrm{k}_{2}$ dan $\mathrm{k}_{3}$ tidak berbeda nyata satu dengan yang lainnya.

Tabel 7. Grade Jamur (mm)

\begin{tabular}{lccc}
\hline \multirow{2}{*}{\multicolumn{1}{c}{ Perlakuan }} & \multicolumn{3}{c}{ Rata-rata diameter tudung berdasarkan Grade } \\
& Gamur $(\mathrm{mm})$ \\
\cline { 2 - 4 } & & Grade $\mathrm{I}$ & Grade $\mathrm{III}$ \\
\hline Ketebalan Media $(\mathrm{M})$ & $2,63 \mathrm{a}$ & $1,25 \mathrm{a}$ & $0,50 \mathrm{a}$ \\
$\mathrm{m}_{0}:$ ketebalan $5 \mathrm{~cm}$ & $2,88 \mathrm{a}$ & $1,00 \mathrm{a}$ & $0,88 \mathrm{a}$ \\
$\mathrm{m}_{1}:$ ketebalan $15 \mathrm{~cm}$ & $14,13 \mathrm{~b}$ & $4,50 \mathrm{a}$ & $1,63 \mathrm{a}$ \\
$\mathrm{m}_{2}:$ ketebalan $25 \mathrm{~cm}$ & $13,25 \mathrm{~b}$ & $2,25 \mathrm{a}$ & $0,57 \mathrm{a}$ \\
$\mathrm{m}_{3}:$ ketebalan $35 \mathrm{~cm}$ & & & \\
\hline Konsentrasi Molase $(\mathrm{K})$ & $5,50 \mathrm{a}$ & $2,00 \mathrm{a}$ & $0,75 \mathrm{a}$ \\
$\mathrm{k}_{0}:$ tanpa molase & $8,63 \mathrm{a}$ & $1,88 \mathrm{a}$ & $1,13 \mathrm{a}$ \\
$\mathrm{k}_{1}:$ molase $5 \mathrm{ml} / 1$ & $11,25 \mathrm{a}$ & $3,13 \mathrm{a}$ & $1,13 \mathrm{a}$ \\
$\mathrm{k}_{2}:$ molase $15 \mathrm{ml} / 1$ & $7,50 \mathrm{a}$ & $2,00 \mathrm{a}$ & $0,75 \mathrm{a}$ \\
$\mathrm{k}_{3}:$ molase $25 \mathrm{ml} / 1$ & & & \\
\hline
\end{tabular}

Keterangan: Angka rata-rata pada kolom yang diikuti huruf yang sama tidak berbeda nyata menurut Uji Jarak Berganda Duncan pada taraf 5\%.

Grade II dan grade III faktor perlakuan ketebalan media tanam menunjukkan semua taraf faktor $\mathrm{m}_{0}, \mathrm{~m}_{1}, \mathrm{~m}_{2}$ dan $\mathrm{m}_{3}$ tidak berbeda nyata antara satu dengan yang lainnya. Faktor perlakuan konsentrasi molase menunjukkan semua taraf faktor $\mathrm{k}_{0}, \mathrm{k}_{1}, \mathrm{k}_{2}$ dan $\mathrm{k}_{3}$ tidak berbeda nyata antara satu dengan yang lainnya.

Kualitas jamur merang dipengaruhi oleh ketersediaan nutrisi yang pada media tumbuh dan kondisi lingkungan yang optimum. Tubuh buah yang tidak sempurna lebih disebabkan oleh kegagalan mempertahankan kondisi lingkungan yang stabil sehingga pembentukan tubuh buah berjalan tidak sempurna (Sinaga, 2006). 
Menurut Agus dkk, (2002) menyatakan kelembapan udara untuk pertumbuhan jamur adalah 75 sampai $85 \%$, tingkat kelembapan $75 \%$ berpengaruh terhadap pembentukan miselium, kelembapan 80 sampai $85 \%$ berpengaruh terhadap pembentukan tubuh buah, kemungkinan pembentukan miselium dari spora akan gagal jika kelembapan teralu rendah dan akan rawan busuk jika kelembapan terlalu tinggi.

\section{KESIMPULAN}

Berdasarkan hasil penelitian mengenai pengaruh ketebalan media tanam dan konsentrasi molase tetes tebu terhadap pertumbuhan dan hasil jamur merang, dapat disimpulkan sebagai berikut :

1. Terjadi interaksi antara perlakuan ketebalan media tanam dan pemberian konsentrasi molase terhadap pertumbuhan jamur merang pada waktu keluar pinhead.

2. Secara mandiri faktor perlakuan ketebalan media tanam dengan ketebalan 25 $\mathrm{cm}\left(\mathrm{m}_{2}\right)$ memberikan nilai tertinggi terhadap parameter pengamatan jumlah jamur periode I, bobot jamur periode I dan II, grade I, II dan III, sedangkan pada faktor perlakuan konsentrasi molase dengan konsentrasi $15 \mathrm{ml} / \mathrm{l}\left(\mathrm{k}_{2}\right)$ memberikan nilai tertinggi terhadap semua parameter pengamatan.

\section{DAFTAR PUSTAKA}

Agus, G.T.K., A. Dianawati., E.S. Irawan dan K. Miharja. 2002 . Budi daya Jamur Konsumsi. Agromedia Pustaka. Jakarta.

Gomez, K.A,. dan A.A. Gomez. 1995. Prosedur Statistika untuk Penelitian Pertanian. Terjemahan dari : Statistical Procedures for Agricultural Research. Penerjemah : E. Sjamsudin dan J.S. Baharsjah. Penerbit Universitas Indonesia. Jakarta.

Hambali dan Erliza,. 2007. Teknologi Bioenergi. Agromedia Pustaka, Jakarta.

Parjimo dan Agus, A,. 2013 Budidaya Jamur (Jamur Merang, Jamur Kuping dan Jamur tiram). : Agromedia. Jakarta.

Purwani,. A. Rofiq dan N. Hidayat,. 2007, Simulasi Model Produksi Etanol dari Molase Oleh Sacharmicyces cerevisia pada Kultur Batch.

Puspaningrum dan Indah. 2013. "Produksi Jamur Tiram Putih (Pleuotus ostreatus) Pada Media Tambahan Molase Dengan Dosis Yang Berbeda". 
Skripsi. Jurusan Biologi FKIP. Universitas Muhammadiyah Surakarta. Surakarta.

Riduan, M., D. Hariyono dan M. Nawawi. 2013. Pertumbuhan dan Hasil Jamur Merang (Volvariella volvacea) pada Berbagai Sistem Penebaran Bibit dan Ketebalan Media. Jurnal Prodsuksi Tanaman. Vol. 1 (1).

Sebayang, F. 2006. Pembuatan Etanol dari molase secara fermentasi Menggunakan Sel Saccharomyces cerevisiae Yang Termobilisasi Pada Kalsium Alginat. Jurnal Technologi Proses 5 (2) Juli $2006: 68$ - 74. ISSN 1412 - 7814. Departemen Kimia Fakultas MIPA Universitas Sumatera Utara. Medan.

Sinaga, 2011. Budidaya Jamur Merang. Penebar Swadaya, Jakarta.

Sinaga, 2011. Budidaya Jamur Merang. Penebar Swadaya, Jakarta.

Sunandar dan bambang. 2010. Budidaya Jamur Merang. Balai Pengkajian Teknologi Pertanian Jawa Barat Balai Besar Pengkajian dan Pengembangan Teknologi Pertanian Badan Penelitian dan Pengembangan Pertanian Kementerian Pertanian 2010. Bandung.

Wijaya., Sheila. 2014. The Secret of Jamur.: FlashBokks. Yogyakarta

Zuyasna., Nasution M dan Fitriani D. 2011. Pertumbuhan dan hasil jamur merang akibat perbedaan media tanam dan konsentrasi pupuk super A-1. J. Floratek. 6:92-10. Semarang. 